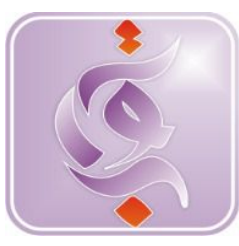

\title{
BISMILLAH, SAYA MENIKAH Studi Kasus Pembentukan Keluarga pada Pasangan Mahasiswa
}

Received: 02 ${ }^{\text {th }}$ September 2019; Revised: 03 ${ }^{\text {th }}$ October 2019; Accepted: $21^{\text {th }}$ October 2019

Muhammad Zulfa Alfaruqy

Dosen Fakultas Psikologi Universitas Diponegoro

Email: zulfa.alfaruqy@gmail.com
Abstrack. Every human being has a requirement to overcome loneliness. In accordance with the theory of early adult development, one of the ways to against it is to build a family. But, couples who did it while just a college student has a complex challenge, especially if deciding taaruf because of religious rules that prohibit relationships before marriage. The aim of this research is to understand the psychological dynamics of college students in building a family through the taaruf process.

This research uses the qualitative method with a case study approach. Researchers involve two subjects of college students who have been married. Data collection was done by interview, observation, and focus group discussion. Couples who build a family by taaruf process, through four stages, there are understanding relations concept, introductions, taaruf, and marriage. They made the interaction in line with Islamic rules that do not allow courtship. The introduction made only a remote view. During the process of taaruf, there is no direct communication to avoid romantic shade. The wedding process becomes an important epiphany in life. Marriage is perceived as a social support that positively affects academic responsibility. Taaruf may be an alternative choice to avoid relationship which is not appropriate with religious rules. College students who decide to build a family, especially through the taaruf process, need to ensure their readiness in academic responsibility.

Keywords: family, relation, student, taaruf

\section{PENDAHULUAN}

Manusia adalah makhluk sosial yang senantiasa membutuhkan kehadiran orang lain. Setiap orang berada dalam kondisi interdependensi pada orang lain (Lange \& Rusbult, 2012) dengan berbagai motivasi yang mengiringi (Rai \& Fiske, 2011). Pada orang yang sudah memasuki masa dewasa awal ada tugas perkembangan yang harus dipenuhi yang berkaitan dengan orang lain yaitu relasi intim. Menurut Fromm (2005) relasi merupakan jalan untuk mengatasi penjara sepi. Risalah kesepian manusia pertama kali dialami oleh Adam lantaran hidup sendiri di surga. Guna melepaskan Adam dari pasung penjara sepi, maka diciptakanlah Hawa dari tulang rusuknya.

Relasi intim laki-laki dan perempuan dijelaskan lebih lanjut dalam Quran Surat Ar Ruum ayat 21. Pada ayat tersebut 
disebutkan bahwa relasi yang diabadikan dalam ikatan pernikahan memberi manfaat berupa ketenangan, ketenteraman, kasih, dan sayang. Sebelum sampai pada tahap pernikahan, pasangan menjalani proses pengenalan. Masyarakat Indonesia, mengalami pro-kontra, terhadap proses pengenalan yang lazim disebut pacaran (dating). Dalam pacaran terdapat relasi romantis yang ditandai dengan adanya keintiman dan gairah yang dialami oleh dua orang secara bersama-sama (Clarke, DeCicco, \& Navara, 2010).

Penelitian yang dilakukan Setyowati (2012), di Kota Semarang, menunjukkan bahwa mahasiswa yang berpacaran dan melakukan perilaku seks di luar nikah bersama pacar/kekasih memaknai bahawa perilaku seks di luar nikah sebagai gaya hidup yang dibiarkan bebas oleh lingkungannya dan didukung oleh teman sebaya. Subjek dalam penelitian tersebut menilai aktivitas kissing dan petting sebagai hal yang biasa karena teman sebaya juga melakukan, sedangkan aktivitas intercourse boleh dilakukan dengan syarat suka sama suka. Pacaran yang menyandarkan pada relasi romantis tanpa komitmen penikahan sejatinya memiliki beberapa kerawanan yang mengancam antara lain perselingkuhan (Helena, Aditari, Diliyanty, 2018) dan kekerasan dalam pacaran atau dating violance (Purnama, 2016).

Dari perspektif agama Islam, pacaran merupakan perilaku yang berdosa karena mendekatkan pelaku pada perzinaan. Padahal zina merupakan perilaku keji dan seburuk-buruk jalan seperti diterangkan dalam QS Al Isra: 32. Islam memiliki diksi taaruf. Taaruf berasal dari bahasa Arab yang berarti saling mengenal. Abdullah (dalam Fillah, 2012) menjelaskan bahwa taaruf ialah proses pengenalan calon suami/istri dengan melibatkan orang lain atau lembaga sebagai perantara dalam pemilihan pasangan yang selasar dengan kriteria, yang mengarah ke pernikahan.

Taaruf memiliki tahapan, misalnya seperti yang dijelaskan Hana (2012). Tahapan tersebut meliputi: a) membuat biodata yang berisi informasi mengenai pihak laki - laki dan perempuan, b) melakukan pertukaran biodata melalui perantara, c) mengadakan pertemuan pihak laki - laki dan perempuan yang difasilitasi perantara, d) mempertemukan kedua keluarga untuk mambangun interaksi, e) menyelenggarakan lamaran. Menurut Widiarti (2010) taaruf mempunyai adab dan tata cara, yaitu meluruskan niat karena Tuhan, menjaga keseriusan taaruf, menjaga kejujuran, melakukan nadzor (melihat), menerima dan menolak dengan baik, menjaga syariat (aturan), mengajak pendamping, menjauhi tempat mencurigakan, menjaga rahasia taaruf, serta melakukan shalat Istikharah untuk keputusan pernikahan.

Pernikahan dapat diartikan sebagai ikatan lahir batin antara seorang pria dan seorang wanita sebagai suami istri dengan tujuan membentuk keluarga atau rumah tangga yang bahagia dan kekal berdasarkan Ketuhanan Yang Maha Esa (UU Nomor 1 Tahun 1974). Menurut Kertamuda (2009) pernikahan merupakan ikatan janji antara suami dan istri yang berimplikasi pada interdependensi di antara keduanya. Dalam pernikahan, dua orang saling berkomitmen secara legal untuk menjalin kedekatan emosional dan fisik, serta membagi tugas dan sumber ekonomi (Olson, Defrain, Skogrand, 2011).

Pernikahan menandai terbentuknya keluarga baru; unit terkecil suatu masyarakat. Keluarga ialah sistem sosial alami yang di dalamnya mengandung 
aturan, peran, bentuk dan kerjasama untuk memenuhi tugas-tugas perkembangan Goldenberg dan Goldenberg (2008). Menurut Koerner dan Fitzpatrick (dalam Lestari, 2012) keluarga mencakup tiga perspektif yaitu struktural, fungsional, dan transaksional. Secara struktural, keluarga dimaknai dengan kehadiran siapa saja yang menjadi anggota keluarga. Secara fungsional, keluarga dimaknai dengan terpenuhinya tugas dan fungsi psikososial. Adapun secara transaksional, keluarga dimaknai dengan pengembangan keintiman antaranggota.

Afiatin (2013) memaparkan bahwa keluarga secara hirarkis mengalami delapan tahap, yaitu: 1) Tahap pasangan pengantin baru, yakni keluarga yang belum memiliki anak; 2) Tahap keluarga dengan anak usia batita, yakni keluarga yang usia anak pertama di bawah 3 tahun; 3) Tahap keluarga dengan anak prasekolah, yakni keluarga yang usia anak pertama antara 36 tahun; 4) Tahap keluarga dengan anak usia sekolah, yakni keluarga yang usia anak pertama berkisar di 6-12 tahun; 5) Tahap keluarga dengan anak remaja, yakni keluarga yang memiliki anak pertama berusia 13-20 tahun; 6) Tahap keluarga sebagai launching centre, yakni anak pertama sampai anak terakhir meninggalkan keluarga untuk membentuk keluarga sendiri; 7) tahap keluarga tengah baya, yakni sudah pensiun dan mengalami sangkar kosong; 8) tahap keluarga lansia, yakni keluarga yang menunggu kematian.

Benokraitis (dalam Alfaruqy, 2018) menjelaskan bahwa ada lima fungsi keluarga yaitu reproduksi, sosialisasi, status sosial, dukungan ekonomi, dan dukungan emosi. Fungsi reproduksi berkaitan dengan aktivitas seksual pasangan suami-istri yang dilegalkan secara agama maupun hukum, sehingga keturunan mendapat jaminan seluruh hakhaknya. Fungsi sosialisasi berhubungan dengan fasilitasi sosial orangtua kepada anak dalam hidup bermasyarakat guna menginternalisasi pengetahuan, keyakinan, sikap, dan nilai-nilai dalam keluarga supaya mampu berinteraksi dengan lingkungan. Fungsi status sosial berkaitan dengan status kelas sosial yang akan diidentifikasi oleh anggota keluarga. Kelas sosial keluarga, seperti kekayaan, pendidikan, dan pengaruh sosial, memberi identitas sosial bagi anggota. Fungsi dukungan ekonomi berkenaan dengan keamanan finansial untuk kebutuhan rumah, perawatan, dan perlindungan, termasuk kebutuhan makanan dan minuman guna kesinambungan hidup. Sumber pendapatan finansial berada pada tanggung jawab suami, meskipun di kekinian zaman banyak istri yang turut membantu suami. Sementara, fungsi dukungan emosi berhubungan dengan pemenuhan kebutuhan rasa cinta, sayang, dan emosi positif lain. Dukungan emosi membuat anggota keluarga menjadi bahagia dalam menjalani hidup.

Fenomena mahasiswa yang memilih untuk menikah dan membentuk keluarga, daripada berpacaran jamak dijumpai di sejumlah kampus. Dari perspektif life span, mahasiswa yang lazim berada pada rentang usia 18 sampai dengan 23 tahun sejatinya menginjak dua fase tahap perkembangan yaitu remaja akhir dan dewasa awal. Menurut Santrock (2012), dewasa awal mempunyai tugas pembentukan relasi intim dengan orang lain, termasuk pembentukan keluarga baru.

Fenomena pernikahan mahasiswa dilematis mengingat dia dihadapkan pada dua peran sekaligus yaitu sebagai peserta didik perguruan tinggi dan suami/istri bagi pasangan masing-masing. Di satu sisi ada 
tanggung jawab akademis yang menanti, di sisi lain ada tanggung jawab fungsi keluarga yang harus dijalani. Tidak berhenti di situ, proses menuju pernikahan pun berada di persimpangan pilihan apakah melalui proses pacaran (dating) atau taaruf yang selaras dengan aturan agama.

Berdasarkan uraian tersebut di atas, maka tujuan penelitian adalah untuk memahami dinamika psikologis pasangan mahasiswa dalam pembentukan keluarga melalui proses taaruf.

\section{METODE}

Peneliti menggunakan metode kualitatif dengan pendekatan studi kasus. Studi kasus merupakan pendekatan yang menuntut peneliti untuk melakukan penyelidikan suatu program, aktivitas, proses, peristiwa, atau sekelompok individu dengan cermat (Creswell, 2013). Penelitian yang tergolong kasus tunggal atau single case ini bertujuan untuk memahami dinamika psikologis pasangan mahasiswa dalam pembentukan keluarga melalui proses taaruf

Subjek dipilih dengan purposif sampling, yaitu teknik pemilihan yang memungkinkan peneliti memilih subjek dan lokasi penelitian sejalan dengan tujuan untuk apa permasalahan pokok akan diteliti (Herdiansyah, 2012). Penelitian melibatkan sepasang mahasiswa suamiistri yang memenuhi kriteria sebagai berikut: a) Pasangan suami-istri yang menikah melalui taaruf; b) Berstatus mahasiswa/i; c) Memiliki anak; serta d) Bersedia untuk menjadi subjek penelitian. Pengumpulan data memakai wawancara, observasi, dan focus group discussion.

Analisis data dilakukan sesuai prosedur analisis penelitian kualitatif yang mengacu pada Creswell (2013). Prosedur tersebut meliputi mengolah dan mempersiapkan data, membaca data secara keseluruhan, menganalisis lebih detail dengan koding data, melakukan kategorisasi dan deskripsi, membuat narasi, menemukan esensi makna, malakukan interpretasi data, serta menyajikan data (lihat Gambar 1).

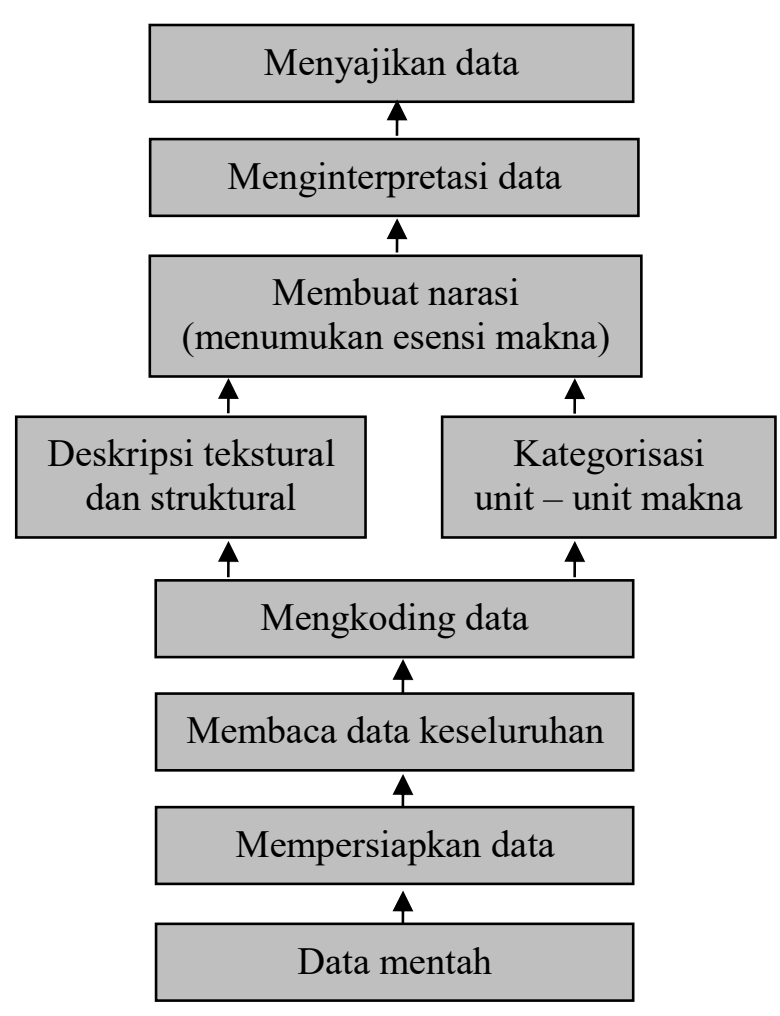

Gambar 1. Alur Analisis Data

\section{HASIL}

\section{Temuan Tema-Tema}

Penelitian dilakukan kepada pasangan mahasiswa salah satu perguruan tinggi di Kota Semarang yang berdomisili Jawa Tengah. Penelitian menemukan ada empat tema (lihat Tabel 1).

Tabel 1. Tema

\begin{tabular}{|ll|}
\hline No & \multicolumn{1}{c|}{ Tema } \\
\hline 1 & Pembentukan Konsep Relasi \\
\hline 2 & Perkenalan \\
\hline 3 & Proses Taaruf \\
\hline 4 & Penikahan \\
\hline
\end{tabular}


Pembentukan Konsep Relasi

Pasangan, baik suami maupun istri, tidak melakukan dating activity sebelum menikah. Perilaku tersebut diambil karena keduanya mempunyai konsep relasi interpersonal berbeda jenis yang relatif sama yaitu regulasi Islam yang melarang relasi intim (kasih sayang) yang bukan marham. Pasangan ini sama-sama tidak menjalin relasi intim, misalnya pacaran, pada masa sebelumnya.

Perkenalan

Kontak pertama pasangan, sebelum menikah, ialah dalam sebuah acara pengajian di masjid. Perkenalan dilakukan tanpa sengaja, tanpa ada kelanjutan interaksi secara langsung. Subjek A, lakilaki, hanya melihat dari kejauhan, namun disertai dengan usaha mendapatkan informasi terkait subjek $\mathrm{B}$, perempuan, dengan cara mengobservasi aktivitas dan membaca tulisan-tulisan di blognya. Usaha tersebut hanya dilakukan sepihak oleh subjek A tanpa diketahui subjek B.

\section{Proses Taaruf}

Pasangan melakukan taaruf sebagai tindak lanjut dari perkenalan dengan melalui perantara yang dalam hal ini ialah ustadz di masjid tempat keduanya bertemu. Pasangan beberapa kali berkomunikasi melalui email guna bertukar informasi lebih lanjut terkait konsep pernikahan, pengasuhan anak, dan manajemen keuangan. Taaruf mencapai puncak (termination) dengan acara khitbah sebagai simbolisasi sosial kesepakatan antara subjek A dan subjek B beserta keluarga. Pasca khitbah, keduanya sama sekali tidak berkomunikasi guna menghindari relasi romantis.

Pernikahan dan Tanggung Jawab Akademis
Prosesi pernikahan ialah pengalaman pertama bagi pasangan tersebut bertatapan secara langsung. Pernikahan dimaknai sebagai tahapan yang membuncahkan rasa bahagia dan tenang karena telah mengamalkan salah satu sunnah, serta rasa bahagia karena bisa melengkapi satu sama lain dalam menyempurnakan agama.

Perubahan status subjek A dan subjek B sebagai sepasang suami dan istri adalah epiphany yang mempengaruhi sepenuh-seluruh kehidupan, termasuk juga dalam kehidupan akademis. Status sosial sebagai pasangan suami-istri membawa keduanya pada aktivitas-aktivitas pemenuhan fungsi reproduksi hingga dukungan sosio-emosional. Adapun status sosial sebagai mahasiswa mengikat pada tanggung jawab akademis.

Kahamilan memiliki efek pada penurunan performa subjek B sebagai mahasiswi tingkat akhir. Sebelum hamil, subjek masih dapat mengerjakan skripsi, namun pada saat hamil atensi pada pengerjaan skripsi menurun. Hal ini tidak bisa dilepasakan dari efek psiko-biologis yang dialami oleh ibu hamil. Di sisi lain, subjek B merasakan efek positif dari pernikahan tersebut, karena subjek A mencurahkan dukungan sosial, misalnya mengantar B menemui subjek penelitian, hingga penelitian skripsi tersebut selesai. Implikasinya subjek A, suami, berbagi waktu antara pencurahan dukungan sosial untuk istri, tanggung jawab ekonomi dalam pencarian nafkah, serta pengerjaan skripsinya sendiri. Implikasi tersebut diakui oleh suami sebagai kondisi yang berat, namun menimbulkan rasa bahagia karena diiringi kesyukuran ibadah.

Kelahiran sang buah hati membawa kebahagiaan tersendiri bagi keluarga kecil tersebut. Fokus keduanya adalah membina keluaga dan mengurus anak. Adapun 
tanggung jawab akademis sebagai mahasiswa hanya menyisakan revisi skripsi dan seremonial kelulusan. Saat ini, pasangan tersebut tinggal di rumah orang tua A. Sehingga, pasangan ini tergolong extended family. Adapun struktur keluarga tersebut ialah sebagai berikut (lihat Gambar 2).

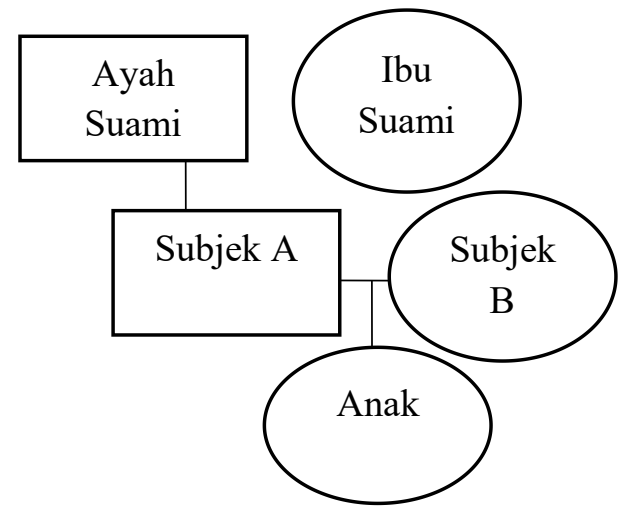

Gambar 2.

Genogram Extended Family Subjek

\section{Dinamika Psikologis}

Pembentukan konsep relasi yang sesuai syariat Islam mengawali dinamika psikologis subjek A (suami) maupun B (istri), bahkan sebelum sampai pada tahap kontak (lihat Gambar 3). Efek dari konsep relasi yang dibentuk meresapi tahap demi tahap relasi.

Tahap kontak, merupakan tahap pertama dalam sebuah relasi interpersonal, yang dalam hal ini berisi pengenalan subjek satu sama lain. Tahap kontak melingkupi persepsi positif resiprokal antara subjek A dan subjek B.

Tahap keterlibatan, merupakan tahap yang membuat subjek A dan subjek B terlibat dalam aktivitas bersama. Tahap ini memiliki tiga fase. Fase pertama, ialah pra taaruf yang mencakup aktivitas harian, seperti kegiatan pengajian dan organisasi bersama. Fase kedua, ialah pasca taaruf di mana intensitas keterlibatan berkurang secara kuantitas namun esensinya muhasabah guna meyakinkan kualitas masing-masing. Fase ketiga, ialah pasca khitbah, di mana keterlibatan tidak ada sama sekali. Hal ini merupakan efek konsep relasi sosial yang sesuai syariat Islam yang melarang relasi romantis yang lazimnya dipenuhi kasih sayang dan dorongan ketertarikan fisik.

Tahap keakraban, merupakan tahap yang diikat dalam komitmen interpersonal. Komitmen interpersonal ini diiringi juga dengan komitmen pernikahan sehingga batasan (boundary) sangat jelas. Pada tahap ini, A dan B memulai eksplorasi karakteristik satu sama lain, dengan tetap berada dalam rangka mempertahankan dan semakin memperkuat relasi.

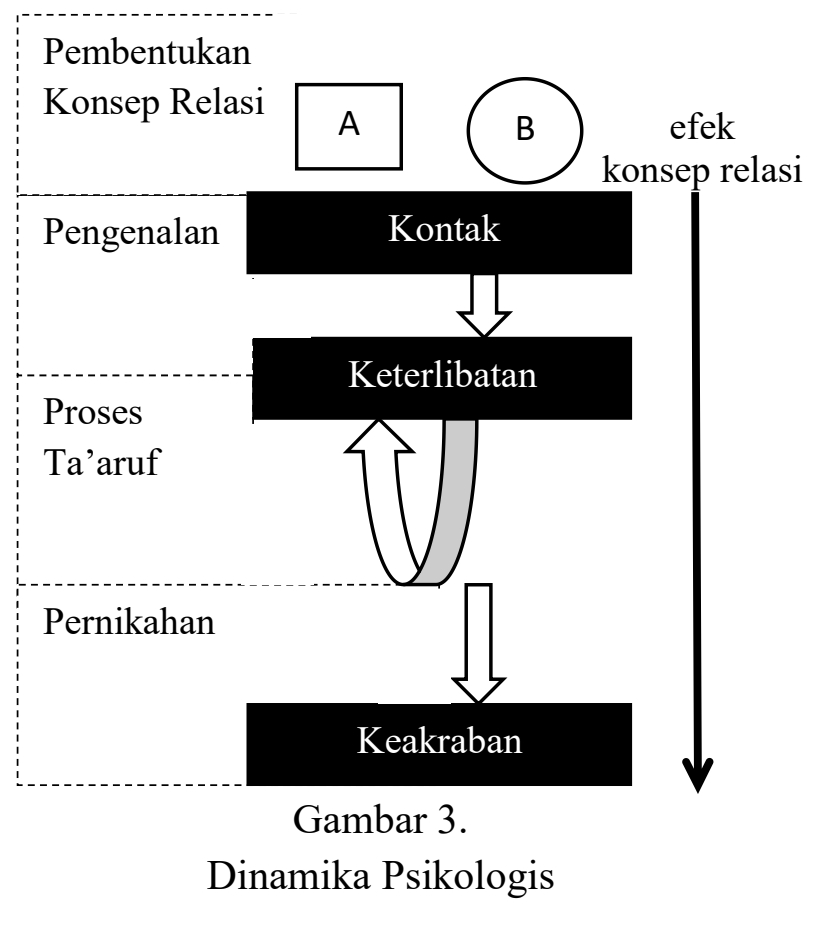

\section{PEMBAHASAN}

Relasi yang disajikan penelitian ini ialah relasi yang memiliki arah pada keintiman (kasih sayang) pada tahap perkembangan dewasa awal. Erikson (dalam Friedman, 2008) menjelaskan bahwa individu yang berusia 20 tahun ke atas mengembangkan rasa cinta. Pada tahap tersebut individu mempunyai tugas 
perkembangan untuk membina hubungan yang lebih mendalam dengan lawan jenis.

Tugas perkembangan ini dipenuhi dengan alternative melalui proses pacaran (dating) atau taaruf yang selaras dengan aturan agama. Dalam agama Islam, pacaran tidak diperbolehkan karena pacaran adalah salah satu pintu terbukanya kemaksiatan dan jalan mendekati zina. Pada kasus ini pasangan memilih untuk taaruf. Pilihan tersebut menghindarkan pada cinta romantis. Menurut Sternberg (1998), cinta romantis adalah hubungan cinta dua individu yang berbeda jenis kelamin yang didasarkan atas unsur keakraban (intimasi, kasih sayang) dan nafsu seksual, tetapi tidak ada niat untuk meneruskan ke jenjang pernikahan.

Kekhasan relasi interpersonal pasangan yang menikah dengan taaruf adalah proses penundaan (delayed process) yang disengaja dari tahap keterlibatan menuju tahap keakraban. Temuan ini menjadi catatan bagi Relationship Stages Theory yang dikembangkan oleh Devito (2003). Penundaan pada tahap tersebut bukan sama sekali stagnan atau menuju pengakhiran hubungan, justru ada penjelasaan lain bahwa penundaan dalam tahap tersebut merupakan proses yang dinamis untuk mencapai tahap keakraban yang optimal (lihat Gambar 4).

efek

konsep relasi

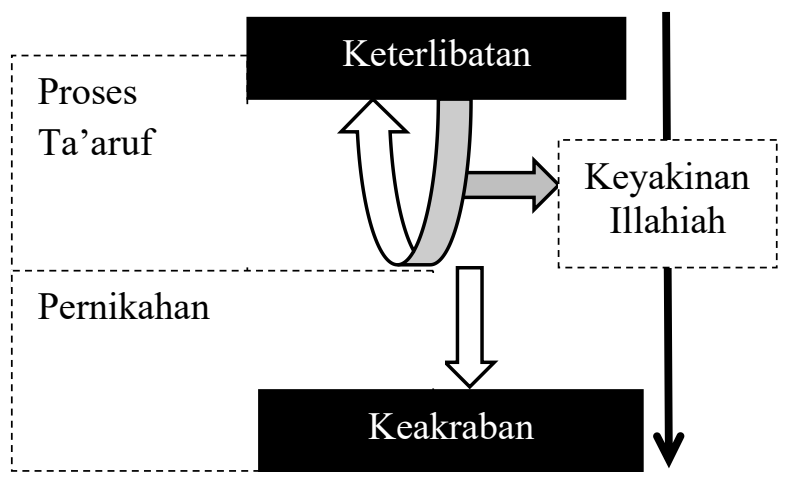

\section{Gambar 4. Pembahasan Relasi}

Proses taaruf ini juga menunjukkan ada keyakinan Illahiah (causa prima), sehingga terdapat penyerahan sepenuhseluruhnya kepada Allah SWT. Dalam perspektif eksistensial Rollo May (2019), walaupun terjadi non being pada level mitwelt, relasi tanpa interaksi pasangan yang menjalani proses taaruf tidaklah berarti hancur, karena yakin akan resilien menuju being in the word pada waktunya, dengan kondisi yang jauh lebih baik.

Pernikahan memberi rasa bahagia, tenang dan saling melengkapi. Terdapat pembagian tugas dalam keluarga tersebut, di mana saat istri hamil, urusan rumah tangga dikerjakan oleh suami. Kondisi muncul dari keluarga tersebut senada dengan Olson, DeFrein dan Skogrand (2011) tentang pendefinisian keluarga bahwa pernikahan merupakan komitemen legal dan emosional antara dua orang yang saling berbagi keintiman emosi dan fisik, tugas serta sumber daya ekonomi.

Pasangan yang berada dalam sebuah system extended family (keluarga batih). Sejatinya pasangan yang menikah telah melakukan diferensiasi diri (differentiation of self), yaitu membedakan diri secara intelektual dan emosional dengan keluarga asal (Goldenberg \& Goldenberg, 2008). Pemutusan tersebut bertujuan untuk memutuskan keterikatan emosi. Lazimnya orang Jawa umumnya, subjek istri dalam penelitian meninggalkan rumah keluarga asalnya untuk mengikuti suami. Sebagai catatan, pasangan ini potensial mengalami proyeksi emosional (family projection process) karena berada system extended family. Dalam hal ini, kakek-nenek dapat akan melekatkan kebiaasaan emosinya kepada cucu-cucunya. 
Temuan lain yang juga menarik dibahas ialah konflik peran yang dialami pasangan suami-istri yang masih berstatus sebagai mahasiswa. Seperti yang dikatakan Burn (2004), dalam kondisi konflik peran ada pertentangan peran saat tuntutan diberikan secara bersamaan. Dalam pandangan tradisional suami bertanggung jawab menafkahi keluarga (Afiatin, 2018), di sisi lain harus menyelesaikan tanggung jawab akademis. Pun, demikian pada istri yang harus mengurusi tanggung jawab domestik dan kondisi biologisnya, di sela aktivitas kampus. Dalam posisi pasangan sudah berada dalam ikatan pernikahan maka yang dibutuhkan ialah rasa kebersyukuran (Indrawati, 2018) dan perspektif yang sesuai dalam memaknai pengalaman pernikahan (Schultz \& Scultz, 2016)

\section{PENUTUP}

\section{Kesimpulan}

Penelitian menunjukkan bahwa pasangan suami-istri yang berstatus sebagai mahasiswa yang menikah melalui proses taaruf melewati empat tahap yaitu pembentukan konsep relasi, perkenalan, taaruf, dan pernikahan. Kekhasan relasi interpersonal pasangan yang menikah dengan taaruf adalah proses penundaan (delayed process) yang disengaja dari tahap keterlibatan menuju tahap keakraban, dengan keyakinan Illahiah menjadi lebih optimal.

Konflik peran sebagai pasangan suami-istri dan mahasiswa membuat pasangan menoleransi pemenuhan atas tanggung jawab akademis dan tanggung jawab keluarga sejauh apa yang dapat diupayakan. Kunci kebahagiaan pasangan terletak bagaimana pemaknaan pernikahan sebagai epifani hidup yang memekarkan rasa bahagia dan tenang karena telah mengamalkan salah satu sunnah, serta rasa bahagia karena bisa melengkapi satu sama lain dalam menyempurnakan agama.

\section{Rekomendasi}

Pernikahan adalah sunnah yang mulia untuk dilaksanakan oleh semua insan. Keputusan menikah pada saat menyadang status sebagai mahasiswa adalah keputusan yang harus diimbangi dengan kesiapan; di antaranya diperoleh dengan mengikuti pelatihan pra-nikah. Khususnya calon suami, sebaiknya sudah memiliki kestabilan ekonomi.

\section{REFERENSI}

Al-Qur'anul Karim

Afiatin, T. (2013). Fungsi Mixed Methods dalam Penelitian Psikologi Keluarga: Pidato Pengukuhan Jabatan Guru Besar Fakultas Psikologi Universitas Gadjah Mada. Yogyakarta: Universitas Gadjah Mada.

Afiatin, T. (2018). Psikologi Perkawinan dan Keluarga. Yogyakarta: Kanisius.

Alfaruqy, M.Z. (2018). Keluarga, Sebuah Perspektif Psikologi. Dalam M.Z. Alfaruqy \& E. S. Indrawati (Eds.), Pemberdayaan Keluarga dalam Perspektif Psikologi (pp. 3-18). Semarang: Penerbit Fakultas Psikologi Universitas Diponegoro.

Burn, S.M. (2004). Groups: Theory and Practice. Melbourne: Wadsworth/ Thomson Learning, Inc.

Clarke, J., DeCicco, T.L., \& Navara, G. (2010). An Investigation Among Dreams with Sexual Imagery, Romantic Jealousy, and Relationship Satisfaction. International Journal of Dream Research 3(1), 54-59.

Creswell, J.W. (2013). Research Design Pendekatan Kualitatif, Kuantitatif, 
111 Jurnal Al-Qalb, Jilid 10, Nomor 2, Oktober 2019, hlm. 103-112

dan Mixed. Yogyakarta: Pustaka Pelajar.

Devito,J. A. (2003). Human communication. New York, NY: Pearson.

Fillah, S.A. (2012). Nikmatnya Pacaran Setelah Pernikahan. Yogyakarta: ProU.

Friedman, H.S., \& Schustack, M.W. (2008). Kepribadian Teori Klasik dan Riset Modern. Edisi Ketiga. Jilid 1. Jakarta : Erlangga.

Fromm, E. (2005). The Art of Loving. Memaknai Hakikat Cinta. Jakarta: Gramedia Pustaka Utama.

Goldenberg, H., \& Goldenberg, I. (2008). Family Therapy: An Overview, Seventh Edition. USA: Thomson Higher Education.

Hana, L. (2012). Taaruf: Proses Perjodohan Sesuai Syari Islam. Jakarta: Elex Media Komputindo.

Herdiansyah, H. (2012). Metodologi Penelitian Kualitatif untuk Ilmu-ilmu Sosial. Jakarta: Salemba Humanika.

Helena, C., Aditari, L.D., \& Diliyanty, M.M.P. (2018). Perbedaan Intensi Berselingkuh antara Laki-laki dan Perempuan Dewasa Muda yang Sedang Menjalani Hubungan Romantis. Prosiding Penguatan Peran Keluarga Indonesia di Era Digital untuk Meningkatkan Kualitas Hidup Masyarakat. Seminar Nasional 29-30 Agustus 2018 di Fakultas Psikologi Undip.

Indrawati, E.S. (2018). Deteksi Dini Pelaku Kekerasan dalam Rumah Tangga. Dalam M.Z. Alfaruqy \& E. S. Indrawati (Eds.), Pemberdayaan Keluarga dalam Perspektif Psikologi (pp. 3-18). Semarang: Penerbit Fakultas Psikologi Universitas Diponegoro.
Lange, P.A.M.V. \& Rusbult (2012). Interdependency Theory. Dalam P. A. M. V. Lange, A. W. Kruglanski, \& E. T. Higgins (Eds.), Handbook of Theories of Social Psychology Volume 2 (pp. 418-438). London: Sage Publication.

Kertamuda. (2009). Konseling Pernikahan untuk Keluarga Indonesia. Jakarta: Penerbit Salemba Humanika.

Lestari, S. (2013). Psikologi Keluarga: Penanaman Nilai dan Penanganan Konflik dalam Keluarga. Jakarta: Kencana Prenada Media Group.

May,R. (2019). Manusia Mencari Dirinya. Yogyakarta: Basabasi.

Olson, D.H., DeFrein, J., \& Skogrand, L. (2011). Marriage \& Families: Intimacy, Diversity, and Strenghs, Seventh Edition. New York: Mc GrawHill.

Punama, F. (2016). Kekerasan dalam Pacaran pada Remaja. Harkat: Media Komunikasi Islam tentang Gender dan Anak, 12(2), 161-170.

Rai, T. S., \& Fiske, A. P. (2011). Moral Psychology is Relationship Regulation: Moral Motives for Unity, Hierarchy, Equality, and Proportionality. Psychological Review, 118(1), 57-75.

Republik Indonesia. (1974). UndangUndang No.1 Tahun 1974 tentang Perkawinan. Lembaran Negara RI tahun 1974, Nomor 1. Sekretarian Negara. Jakarta.

Santrock, J.W. (2012). Remaja Edisi 11 Jilid 2. Jakarta: Erlangga.

Setyowati, D. (2012). Gambaran Perilaku Seksual Pranikah pada Mahasiswa Pelaku Seks Pranikah di Universitas X Semarang. Prosiding Seminar Hasil Penelitian Unimus 2012.

Schultz, D.P. \& Schultz, E.P. (2016). Teori Kepribadian. Jakarta: EGC. 
112 Jurnal Al-Qalb, Jilid 10, Nomor 2, Oktober 2019, hlm. 103-112

Sternberg, Robert. J. (1998). Love is Story :A New Theory of Relationship. New York : Oxford University Press.
Widiarti, A. (2010). Tak Kenal Maka

Taaruf. Solo: Era Adicitra Intermedia. 